\title{
Individual variation in the relation between body temperature and energy expenditure in response to elevated ambient temperature.
}

Citation for published version (APA):

van Marken Lichtenbelt, W. D., Westerterp-Plantenga, M. S., \& Hoydonck van, P. (2001). Individual variation in the relation between body temperature and energy expenditure in response to elevated ambient temperature. Physiology \& Behavior, 73((1-2)), 235-242. https://doi.org/10.1016/S00319384(01)00477-2

Document status and date:

Published: 01/01/2001

DOI:

10.1016/S0031-9384(01)00477-2

Document Version:

Publisher's PDF, also known as Version of record

Document license:

Taverne

Please check the document version of this publication:

- A submitted manuscript is the version of the article upon submission and before peer-review. There can be important differences between the submitted version and the official published version of record.

People interested in the research are advised to contact the author for the final version of the publication, or visit the DOI to the publisher's website.

- The final author version and the galley proof are versions of the publication after peer review.

- The final published version features the final layout of the paper including the volume, issue and page numbers.

Link to publication

\footnotetext{
General rights rights.

- You may freely distribute the URL identifying the publication in the public portal. please follow below link for the End User Agreement:

www.umlib.nl/taverne-license

Take down policy

If you believe that this document breaches copyright please contact us at:

repository@maastrichtuniversity.nl

providing details and we will investigate your claim.
}

Copyright and moral rights for the publications made accessible in the public portal are retained by the authors and/or other copyright owners and it is a condition of accessing publications that users recognise and abide by the legal requirements associated with these

- Users may download and print one copy of any publication from the public portal for the purpose of private study or research.

- You may not further distribute the material or use it for any profit-making activity or commercial gain

If the publication is distributed under the terms of Article $25 f a$ of the Dutch Copyright Act, indicated by the "Taverne" license above, 


\title{
Individual variation in the relation between body temperature and energy expenditure in response to elevated ambient temperature
}

\author{
Wouter D. van Marken Lichtenbelt*, Margriet S. Westerterp-Plantenga, Pascale van Hoydonck \\ Department of Human Biology, Maastricht University, P.O. Box 616, 6200 MD, Maastricht, Netherlands
}

Received 8 November 2000; received in revised form 12 February 2001; accepted 19 March 2001

\begin{abstract}
The question we address here is whether a mild increase in environmental temperature affects body temperature and energy expenditure, focusing on the individual variation in the relation between energy expenditure and body temperature. We studied eight normal weight healthy females, $48 \mathrm{~h}$ at an ambient temperature of $22^{\circ} \mathrm{C}$, and $48 \mathrm{~h}$ at $27^{\circ} \mathrm{C}$. Energy expenditure (EE) was measured in a respiration chamber. Subjects' skin temperature was measured continuously from 8:00 a.m. until 12:00 p.m.: forehead, infraclavicular zone, thigh, hand, and foot. Core temperature was determined tympanically. Body composition was determined by under water weighing. Exposure to $27^{\circ} \mathrm{C}$ caused a significant increase in body temperature (both skin and core), a decrease in temperature gradients, and a decrease in energy expenditure. At $27^{\circ} \mathrm{C} 24 \mathrm{~h} \mathrm{EE}$, adjusted for body composition, was significantly related to body tympanic temperature. The decrease in $24 \mathrm{~h} \mathrm{EE}$, at $27^{\circ} \mathrm{C}$ ambient temperature, was significantly, negatively related to the increase in $T_{\text {tym }}$, indicating individual responses in adaptation to elevated ambient temperature. Changes in temperature gradient (comparing $27^{\circ} \mathrm{C}$ with $22^{\circ} \mathrm{C}$ ) were negatively related to changes in EE. This shows that individuals differ in their response to an increase in environmental temperature regarding the relative contribution of insulative or metabolic adjustments. (C) 2001 Elsevier Science Inc. All rights reserved.
\end{abstract}

Keywords: Metabolic rate; Obesity; Respiration chamber

\section{Introduction}

Studies on the effect of ambient temperature on metabolism in humans often concentrate on either energy expenditure (EE) [1-3], or body temperature [4-6]. Few studies look at the interaction of energy metabolism and body temperature [7-9]. Looking at both EE and body temperature distribution may provide insight in individual differences in response to changes in environmental temperature. Different sites of the body have different temperatures and their response to a variation in environmental temperature is site-specific [10]. The body can be divided in two compartments: the thermal core and the thermal shell [11]. The thermal core consists of intracranial, intrathoracic, and intraabdominal contents and its temperature is relatively constant $[2,12,13]$. The thermal shell, including the skin, subcutaneous tissue, and the limbs, has temperatures that fluctuate much more $[14,15]$. Most of the energy produced within the

\footnotetext{
* Corresponding author. Tel.: +31-43-3881629; fax: +31-43-3670976.

E-mail address: markenlichtenbelt@hb.unimaas.nl (W.D. van Marken Lichtenbelt*).
}

core is dissipated into the environment via the body's surface. It follows that under thermal neutral conditions, the skin temperature is lower than the core temperature and that the skin temperature varies more with the ambient temperature. Indeed, mild cold has shown to increase the temperature gradient, i.e., a reduction of peripheral temperature at relatively constant core temperature [16].

With respect to EE, it has been shown that a decrease in energy metabolism parallels an increase of ambient temperature [17], and vice versa $[1,18]$. One study has shown a significant relationship between body size adjusted metabolic rate and body temperature [7]. They showed in their analyses of the data from the Minnesota Semi-Starvation Study [19] that body temperature and adjusted [for body fat, body fat free mass (FFM), age, and gender] metabolic rate were significantly related. Though throughout the starvation experiments and refeeding, the individual temperatures dropped and increased again, it was shown that the interindividual differences in body temperature remained. These results indicate the existence of a possibly genetically determined interindividual difference in body temperature set(tling)-points. 
Table 1

Physical characteristics of the eight female subjects

\begin{tabular}{lcl}
\hline Location & Mean & Range \\
\hline Age (year) & 22.6 & $19.0-25.0$ \\
Height $(\mathrm{m})$ & 1.69 & $1.61-1.76$ \\
Weight $(\mathrm{kg})$ & 63.9 & $48.6-76.1$ \\
BMI $\left(\mathrm{kg} / \mathrm{m}^{2}\right)$ & 22.2 & $17.2-25.0$ \\
Body fat $(\%)$ & 27.8 & $21.1-33.2$ \\
FFM & 46.1 & $38.4-52.8$
\end{tabular}

The questions we address here are whether an individual variation in $\mathrm{EE}$ is related to body temperature, and how a mild increase in environmental temperature affects both body temperature and EE.

\section{Materials and methods}

Eight healthy female volunteers participated in the study. The body mass, body mass index (BMI), body composition (\% body fat) was within normal range for young females (Table 1).

The Medical Ethical Committee of Maastricht University approved the study.

\subsection{Body composition}

Whole body density was determined by underwater weighing in the morning in fasted state. Body weight was measured with a digital balance with an accuracy of $0.01 \mathrm{~kg}$ (Sauter, type E1200). Lung volume was measured simultaneously with the helium dilution technique using a spirometer (Volugraph 2000, Mijnhardt). Percentage body fat was calculated using the equation of Siri [20]. FFM (kg) was calculated by subtracting fat mass from body mass.

\subsection{Energy expenditure}

Each out of two tests lasted $48 \mathrm{~h}$. The test took place in a $14-\mathrm{m}^{3}$ respiration chamber, as described in detail by Schoffelen et al. [21]. The room is ventilated with fresh air. The ventilation rate was measured with a dry gas meter (G4 Schlumberger, The Netherlands) and amounted to 70-80 l/ min. The relative humidity was set at $55 \%$ at both $22^{\circ} \mathrm{C}$ and $27^{\circ} \mathrm{C}$. Physical activity was monitored by means of a radar system, based on the Doppler principle [21]. The sensitivity of the radar system is described elsewhere [21,22].

Twenty-four hours EE was determined from the $\mathrm{O}_{2}$ consumption and the $\mathrm{CO}_{2}$ production according to Weir [23]. Sixteen hours EE (from 8:00 a.m. to 12:00 p.m.) was also calculated for comparison with body temperature measurements from the same time interval (see below). Sleeping metabolic rate (SMR) was calculated as the lowest mean EE over three consecutive hours between 12:00 p.m. and 7:00 a.m. Twenty-four hours diet-induced thermogenesis (DIT) was determined as the increase in EE above SMR, corrected for activity-induced EE (AEE). This was achieved by plotting EE against radar output. The intercept of the regression line at the offset of the radar, thus at zero physical activity, represents the $\mathrm{EE}$ in the inactive state: resting energy expenditure (RMR), consisting of SMR plus DIT. DIT was calculated by subtracting SMR from RMR [2426]. AEE was obtained by subtracting DIT and SMR from $24 \mathrm{~h}$ EE. All EE components are expressed in M/24 h.

\subsection{Body temperature}

Subjects' skin temperature was measured continuously from 8:00 a.m. until 12:00 p.m. by means of thermistor surface contact probes (YSI Series 400 type: 409B, accuracy $\pm 0.1^{\circ} \mathrm{C}$ ) fixed on the skin with thin, air-permeable adhesive surgical tape. The probes were applied to the following standardized regions: forehead $\left(T_{\text {for }}\right)$, infraclavicular zone $\left(T_{\mathrm{in}}\right)$, and on nondominant sides of thigh $\left(T_{\mathrm{th}}\right)$, hand $\left(T_{\mathrm{ha}}\right)$, and foot $\left(T_{\mathrm{fo}}\right)$. Distal skin temperatures were calculated from means of $T_{\mathrm{ha}}$ and $T_{\mathrm{fo}}$, while proximal skin temperatures were derived by averaging $T_{\text {for }}, T_{\mathrm{in}}$, and $T_{\mathrm{th}}$. Skin temperature measurements were used to calculate average $16 \mathrm{~h}$ values. The thermometric probes were calibrated to within $0.05^{\circ} \mathrm{C}$ in a water bath against a reference mercury thermometer (accuracy: $0.02^{\circ} \mathrm{C}$ ).

Tympanic temperature $\left(T_{\text {tym }}\right)$ was measured using an infrared thermometer (Genius, M3000A) with a built-in offset value of $1.44^{\circ} \mathrm{C}$. Temperature measurements were thoroughly explained to the subjects before entering the respiration chambers.

\subsection{Protocol}

The study took place at the Department of Human Biology, Maastricht University, during the winter season

Table 2

Mean temperature of proximal skin $\left(T_{\text {prox }}\right)$, distal skin $\left(T_{\text {dist }}\right)$, and tympanic $\left(T_{\text {tym }}\right)$ and results from ANOVA repeated measures test

\begin{tabular}{|c|c|c|c|c|c|c|}
\hline \multirow{2}{*}{ Location } & \multirow{2}{*}{$22^{\circ} \mathrm{C}$ (Day 1$)$} & \multirow{2}{*}{$22^{\circ} \mathrm{C}$ (Day 2) } & \multirow{2}{*}{$27^{\circ} \mathrm{C}$ (Day 1$)$} & \multirow{2}{*}{$27^{\circ} \mathrm{C}$ (Day 2) } & \multicolumn{2}{|l|}{ ANOVA $P$ value } \\
\hline & & & & & Between subjects & Between treatments \\
\hline$T_{\text {tym }}$ & $37.04^{12} \pm 0.32$ & $36.95^{34} \pm 0.30$ & $37.39^{13} \pm 0.28$ & $37.31^{24} \pm 0.35$ & .08 & .005 \\
\hline$T_{\text {prox }}$ & $32.02^{12} \pm 0.40$ & $31.77^{34} \pm 0.49$ & $34.05^{13} \pm 0.35$ & $33.87^{24} \pm 0.41$ & .96 & .0001 \\
\hline$T_{\text {dist }}$ & $31.13^{12} \pm 0.55$ & $31.02^{34} \pm 0.61$ & $33.89^{13} \pm 0.33$ & $33.68^{24} \pm 0.42$ & .98 & .0001 \\
\hline
\end{tabular}

Mean \pm standard deviation. Significant differences of post hoc test between means indicated by identical superscript numbers. 
Table 3

Temperature gradient of core temperature (tympanic $-T_{\mathrm{tym}}$ ) and skin temperature (proximal $-T_{\text {prox }}$ and distal $-T_{\mathrm{dist}}$ ), and results from ANOVA repeated measures test

\begin{tabular}{|c|c|c|c|c|c|c|}
\hline \multirow{2}{*}{ Difference } & \multirow{2}{*}{$22^{\circ} \mathrm{C}$ (Day 1$)$} & \multirow{2}{*}{$22^{\circ} \mathrm{C}$ (Day 2) } & \multirow{2}{*}{$27^{\circ} \mathrm{C}$ (Day 1 ) } & \multirow{2}{*}{$27^{\circ} \mathrm{C}$ (Day 2) } & \multicolumn{2}{|l|}{ ANOVA $P$ value } \\
\hline & & & & & Between subjects & Between treatments \\
\hline$T_{\mathrm{tym}}-T_{\mathrm{dist}}$ & $5.91^{12} \pm 0.79$ & $5.93^{34} \pm 0.79$ & $3.50^{13} \pm 0.38$ & $3.64^{24} \pm 0.37$ & .94 & .0001 \\
\hline$T_{\text {tym }}-T_{\text {prox }}$ & $5.02^{12} \pm 0.67$ & $5.18^{34} \pm 0.64$ & $3.34^{13} \pm 0.31$ & $3.45^{24} \pm 0.32$ & .86 & .0001 \\
\hline$T_{\text {prox }}-T_{\text {dist }}$ & $0.89^{12} \pm 0.36$ & $0.75^{34} \pm 0.36$ & $0.16^{13} \pm 0.17$ & $0.19^{24} \pm 0.15$ & .37 & .0001 \\
\hline
\end{tabular}

Mean \pm standard deviation. Significant differences of post hoc test between means indicated by identical superscript numbers.

from November 1998 to March 1999. Subjects stayed two times for $48 \mathrm{~h}(9: 00$ p.m. $-9: 00$ p.m. $)$ in the respiration chamber, once at $22^{\circ} \mathrm{C}$, and once at $27^{\circ} \mathrm{C}$, in random order. Measurements were performed during the second week of the menstrual cycle, which is before ovulation. The temporal interval between two tests was 4 weeks. Food composition and regimens at $22^{\circ} \mathrm{C}$ and $27^{\circ} \mathrm{C}$ were identical (breakfast: whole wheat bread, apricot jam, and blueberry jam, sweet spicy biscuit, coffee, tea, or water; snacks: chocowafer cookies or wheat cookies or cake, unsweetened orange juice; lunch: lasagne bolognaise or macaroni with cheese and ham or nasi goreng, water, vanilla ice cream, milk chocolate; snacks: chocowafer cookies or wheat cookies or cake, fruit (apple, banana, kiwi, mandarin, or orange), water; dinner: toast or sandwich with Gouda cheese $48+$, ham, salad, tomato, full-fat fruit yogurt or vanilla dessert; snacks: paprika crisps and salt crisps, water). Subjects were fed in energy balance on the first day and ad libitum on the second day [27]. The clothing was identical during all experiments, was tested in advance, and was comfortable at both ambient temperatures. Daily activities were standardized by describing every hour and sometimes every $15 \mathrm{~min}$ what the subjects were supposed to do. It included household activities, standardized extensive aerobic exercise, sedentary activities such as reading and watching television (see Appendix A). Meal and snack times were also standardized.

\subsection{Statistics}

Body temperatures and $\mathrm{EE}$ of days $27^{\circ} \mathrm{C}$ (Day 1), $27^{\circ} \mathrm{C}$ (Day 2), $22^{\circ} \mathrm{C}$ (Day 1), and $22^{\circ} \mathrm{C}$ (Day 2) were compared using analyses of variance (ANOVA) repeated measures with Scheffe's $F$ test post hoc.

To assess the relationship between body temperature and $24 \mathrm{~h}$ EE, $16 \mathrm{~h}$ EE, SMR, and AEE, EE parameters were adjusted according to predictive equations determined by multiple regression of EE (in MJ/day) against FM and FFM (in $\mathrm{kg}$ ) [28]. The adjusted metabolic rate, or residual, was calculated by subtracting the predicted value from the measured metabolic rate.

Statistical analyses was performed using STATVIEW SE + Graphics, ABACUS concepts, Berkeley, CA. Outcomes were regarded as statistically significantly different if $P<.05$.

\section{Results}

Body weight of the subjects did not change over each experimental period of $48 \mathrm{~h}$, and between each experimental period.

Tympanic temperature and skin temperatures were significantly elevated at $27^{\circ} \mathrm{C}$ (both days) compared to $22^{\circ} \mathrm{C}$ (both days). This also holds for all measured skin temperatures, and for the derived proximal and distal temperatures (Table 2). Temperature gradients, i.e., differences between core temperatures and skin temperatures, and proximal skin and distal skin temperatures, decreased significantly comparing $27^{\circ} \mathrm{C}$ with $22^{\circ} \mathrm{C}$ (Table 3).

$24 \mathrm{~h} \mathrm{EE}$ and $16 \mathrm{~h}$ EE were significantly decreased at $27^{\circ} \mathrm{C}$ compared to $22^{\circ} \mathrm{C}$ at both days, as did DIT and AEE (Table 4) [27]. SMR did not differ significantly comparing days with different ambient temperatures. During all days both $24 \mathrm{~h}$ EE and $16 \mathrm{~h}$ EE were significantly related to

Table 4

$\mathrm{SMR}, 24 \mathrm{~h}$ EE, and AEE in $\mathrm{MJ} / 24 \mathrm{~h}$, and results from ANOVA repeated measures test

\begin{tabular}{llllll}
\hline & $22^{\circ} \mathrm{C}$ (Day 1) & $22^{\circ} \mathrm{C}$ (Day 2) & $27^{\circ} \mathrm{C}$ (Day 1) & $27^{\circ} \mathrm{C}$ (Day 2) & $\begin{array}{l}\text { ANOVA } P \text { value } \\
\text { Between subjects }\end{array}$ \\
SMR & $5.59^{12} \pm 0.66$ & $5.92^{2} \pm 0.67$ & $5.73 \pm 0.79$ & $5.83^{1} \pm 0.50$ & .0001 \\
$24 \mathrm{~h} \mathrm{EE}$ & $9.90^{12} \pm 1.47$ & $9.76^{34} \pm 1.67$ & $9.10^{13} \pm 1.17$ & $9.01^{24} \pm 1.08$ & .0001 \\
B h EE & $11.64^{12} \pm 1.88$ & $11.28^{34} \pm 2.09$ & $10.50^{13} \pm 1.34$ & $10.25^{24} \pm 1.31$ & .0001 \\
AEE & $3.31^{1} \pm 1.05$ & $3.10^{2} \pm 1.12$ & $2.71^{1} \pm 0.39$ & $2.42^{2} \pm 0.48$ & .0001 \\
DIT & $1.01^{1} \pm 0.18$ & $0.74 \pm 0.11$ & $0.66^{1} \pm 0.22$ & $0.76 \pm 0.26$ & .001 \\
\hline
\end{tabular}

Mean \pm standard deviation. Significant differences of post hoc test between means indicated by identical superscript numbers. 


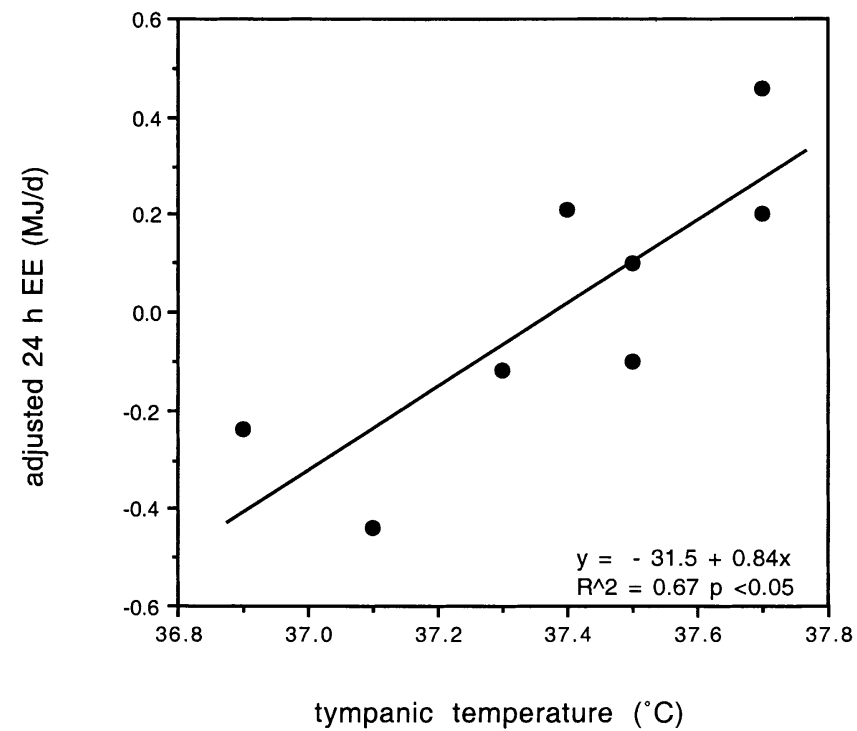

Fig. 1. $24 \mathrm{~h}$ EE, adjusted for FFM and fat mass, in relation to tympanic temperature at $27^{\circ} \mathrm{C}$ ambient temperature, Day 1.

FFM and FM ( $R^{2}$ varied from .81 to .95$)$. These relations were used to calculate residuals for adjustment for FFM and FM.

At $22^{\circ} \mathrm{C}$, there were no correlations between $24 \mathrm{~h} \mathrm{EE}, 16$ $\mathrm{h}$ EE, or SMR (all adjusted for FFM and FM) and body temperature ( $T_{\text {tymp }}, T$ skin). However, at $27^{\circ} \mathrm{C}$, adjusted $24 \mathrm{~h}$ $\mathrm{EE}$ and $16 \mathrm{~h} \mathrm{EE}$ were significantly positively related to tympanic temperature on both days $\left[24 \mathrm{~h} \mathrm{EE}: 27^{\circ} \mathrm{C}\right.$ (Day 1), $P<.05, R=.82 ; 27^{\circ} \mathrm{C}$ (Day 2): $P<.05, R=.78$; see example in Fig. $1 ; 16 \mathrm{~h} \mathrm{EE:} 27^{\circ} \mathrm{C}$ (Day 1 ), $P<.05, R=.73 ; 27^{\circ} \mathrm{C}$ (Day

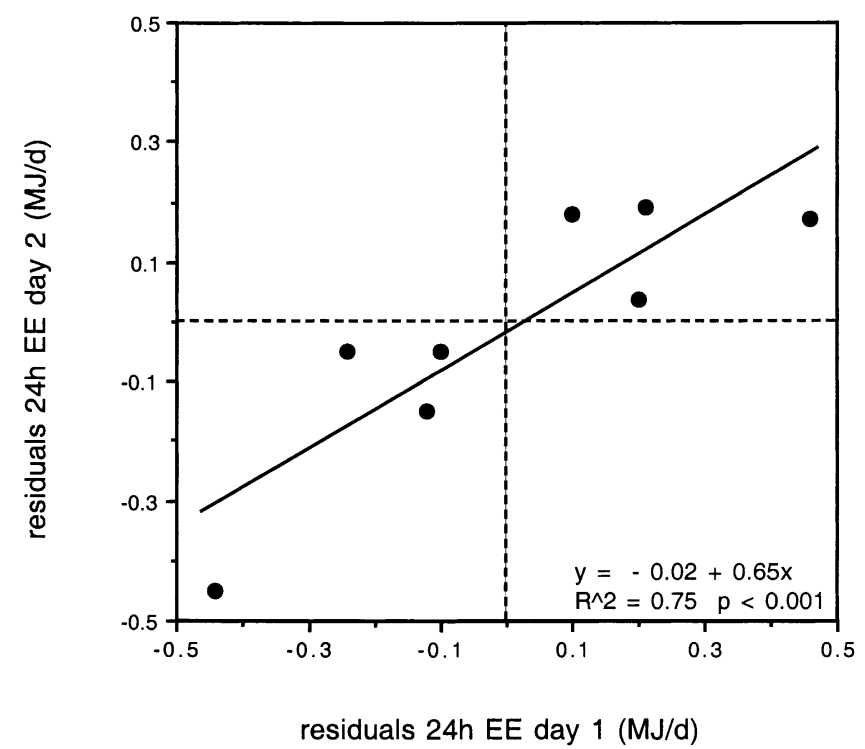

Fig. 2. Residuals of 24 EE of Day 2 in relation to residuals of 24 EE of Day 1 , at $27^{\circ} \mathrm{C}$ ambient temperature.

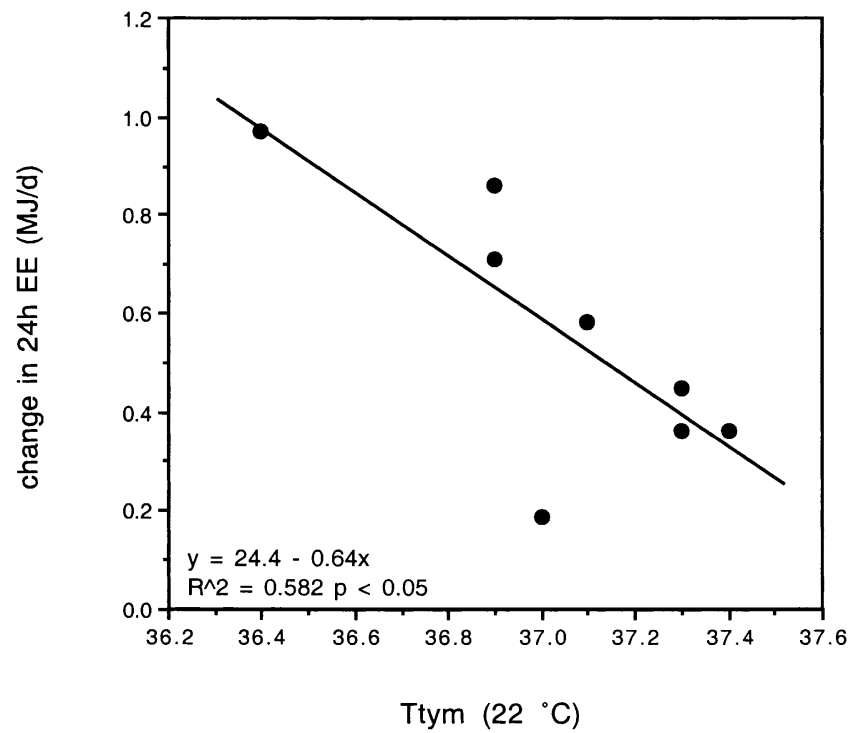

Fig. 3. Change in $24 \mathrm{~h} \mathrm{EE}$, from $27^{\circ} \mathrm{C}$ (day 1) to $22^{\circ} \mathrm{C}$ (day 1), in relation to the tympanic temperature at $22^{\circ} \mathrm{C}$ ambient temperature.

2): $P<.05, R=.71]$. No relations were found between $24 \mathrm{~h}$ $\mathrm{EE}$ or $16 \mathrm{~h} \mathrm{EE}$ and skin temperature. There was also no significant relation with adjusted SMR and body temperatures at $27^{\circ} \mathrm{C}$. The adjusted AEE was significantly related to $T_{\text {tym }}$ at $27^{\circ} \mathrm{C}$ on Day $2\left(P<.05 ; R^{2}=.81\right)$.

The relative magnitude of the $24 \mathrm{~h}$ EE (and $16 \mathrm{~h} \mathrm{EE}$ ) was individual-specific as indicated by the significant correlation between adjusted $24 \mathrm{~h}$ EE of different days (ANOVA repeated measures: between subjects $P<.0001$; between days: $P>.98$; see example in Fig. 2).

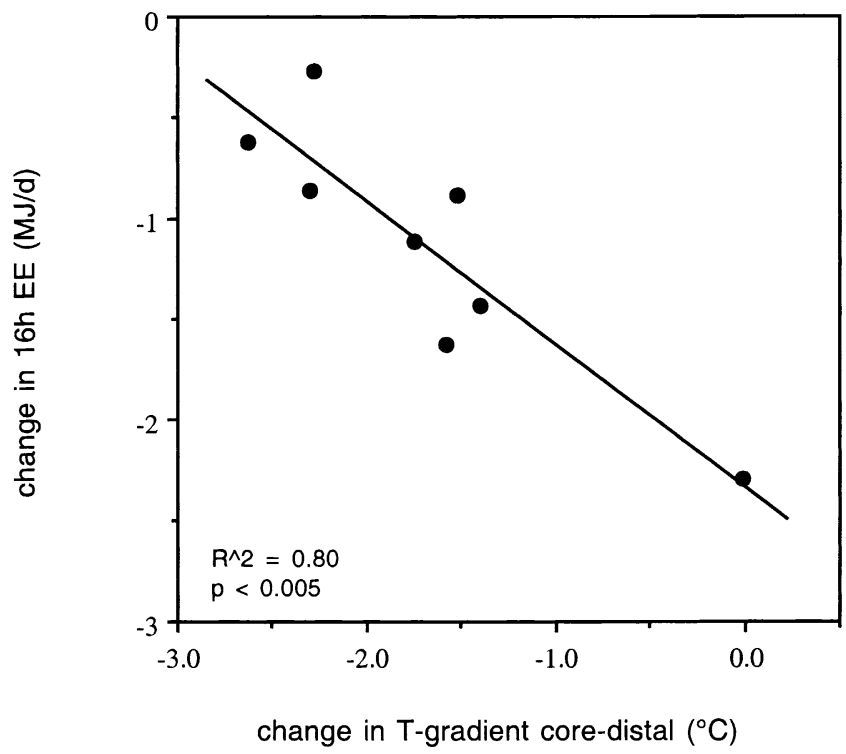

Fig. 4. Change in $16 \mathrm{~h} \mathrm{EE}$, from $27^{\circ} \mathrm{C}$ (day 1) to $22^{\circ} \mathrm{C}$ (day 1), in relation to the change in temperature gradient $\left(T_{\mathrm{tym}}-T_{\mathrm{dis}}\right)$ from $27^{\circ} \mathrm{C}$ (day 1$)$ to $22^{\circ} \mathrm{C}$ (day 1). 
The mean differences of tympanic temperatures between $27^{\circ} \mathrm{C}$ and $22^{\circ} \mathrm{C}$ and the mean differences of EE between $27^{\circ} \mathrm{C}$ and $22^{\circ} \mathrm{C}$ were significantly negatively related $(24 \mathrm{~h}$ EE: $R^{2}=-.67, P<.01 ; 16$ h EE: $\left.R^{2}=-.72, P<.01\right)$. The magnitude of these changes were related to the $T_{\text {tym }}$ at $22^{\circ} \mathrm{C}$ on Day 1 (change in $24 \mathrm{~h} \mathrm{EE}$ and $T_{\text {tym }} 22^{\circ} \mathrm{C}: R^{2}=.58, P<.05$, Fig. 3; change in $16 \mathrm{~h} \mathrm{EE}$ and $T_{\text {tym }} 22^{\circ} \mathrm{C}: R^{2}=.61, P<.05$; change in $T_{\mathrm{tym}}$ and $\left.T_{\mathrm{tym}} 22^{\circ} \mathrm{C}: R^{2}=.59, P<.05\right)$. The change in AEE was also related to $T_{\mathrm{tym}}\left(R^{2}=.78, P<.005\right)$. To find out about the contribution of changes in activity, we tested whether radar counts differed between test days. There were no significant differences in radar counts $(P>.05)$, indicating that our activity protocol worked out well.

Finally, the change in $\mathrm{EE}$, from $27^{\circ} \mathrm{C}$ to $22^{\circ} \mathrm{C}$, was negatively related to the change in temperature gradient (16 h EE and gradient "core-proximal" Day 1: $R^{2}=.77$, $P<.005$; Day 2: $R^{2}=.62, P<.05 ; 16 \mathrm{~h} \mathrm{EE}$ and gradient "core-distal" Day 1: $R^{2}=.80, P<.005$, see Fig. 4; Day 2: $\left.R^{2}=.54, P<.05\right)$. These relations were also significant for 24 $\mathrm{h}$ EE values.

\section{Discussion}

Short-term exposure $(24 \mathrm{~h})$ to $27^{\circ} \mathrm{C}$ of normal-weight women who were used to an ambient temperature of $22^{\circ} \mathrm{C}$ (normal temperature in the building and in most rooms in the Netherlands) caused a significant increase in body temperature (both skin and core), a decrease in temperature gradients, and a decrease in $\mathrm{EE}$. At $27^{\circ} \mathrm{C}$ adjusted $24 \mathrm{~h} \mathrm{EE}$ and $16 \mathrm{~h}$ EE were significantly related to body core temperature (tympanic temperature). The decrease in $24 \mathrm{~h} \mathrm{EE}$ and $16 \mathrm{~h} \mathrm{EE}$, at $27^{\circ} \mathrm{C}$ ambient temperature, were significantly negatively related to the increase in $T_{\mathrm{tym}}$. The change in EE was negatively related to the change in temperature gradient, indicating that individuals differ in their response to an increase in environmental temperature.

Tympanic temperature is regarded as a very sensitive measurement of core temperature. Using infrared thermometers is disputable [29-31], because apart from the eardrum, some of the ear canal is measured. The relative importance of the ear canal is determined by intraindividual differences. However, these differences were compensated for in this study, because the subjects served as their own control. Problems with the IR thermometer are especially evident in very hot environments, intensive exercise, and during fever. For comparative studies under less extreme situations, like in this study, IR tympanic measurements correlate well with the body core temperature (e.g., Refs. $[29,32])$. Notwithstanding these facts, absolute uncorrected values are most probably lower than the actual tympanic temperatures.

The small but significant increase in core body temperature at $27^{\circ} \mathrm{C}$ compared to $22^{\circ} \mathrm{C}$ ambient temper- ature is comparable to earlier studies that found slight but not statistically significant increases of rectal temperature at increasing ambient temperature [16,17]. This increase went hand in hand with a larger increase in skin temperature and a significant drop in metabolic rate, which is consistent with studies on BMR $[16,17]$. The reduction of $24 \mathrm{~h} \mathrm{EE}$ at $27^{\circ} \mathrm{C}$ is also consistent with a more recent study by Dauncey [1]. This reduction can be due to a reduction in RMR, DIT, and/or AEE. We found no reduction in RMR, but indeed, DIT and AEE were significantly reduced at $27^{\circ} \mathrm{C}$, and thus contribute to the reduction in $24 \mathrm{~h}$ EE. To find out if despite a standardized activity protocol activities were affected by environmental temperature, we tested whether radar counts between days differed. This was not the case, underlining that our activity protocol suited our purpose. How then could AEE be affected? Differences in AEE can be explained by differences in muscle tone, ranging from energy expended on maintaining different postures, change in posture, and small movements including fidgeting. This has been described as nonexercise activity thermogenesis or NEAT [33].

For the study of the relation between BT and EE, only 24 $\mathrm{h}$ EE, $16 \mathrm{~h}$ EE, DIT, and AEE can be studied. RMR has not been measured separately and during sleep (night) the core BT was not measured. The relation between adjusted $24 \mathrm{~h}$ EE or $16 \mathrm{~h} \mathrm{EE}$ and $T_{\text {tym }}$ was significant at both days at $27^{\circ} \mathrm{C}$. The significant correlation between adjusted $24 \mathrm{~h}$ EE of different days makes clear that this response was individual-specific.

Apart from possible differences in RMR, the relation between adjusted $24 \mathrm{~h}$ EE or $16 \mathrm{~h} \mathrm{EE}$ and body temperature can be explained by differences in activity. Indeed, adjusted AEE was significantly related to $T_{\text {tym }}$, but on one day $\left[27^{\circ} \mathrm{C}\right.$ (Day 2)] only. From this study, the relative contribution of AEE or RMR to the relation between $24 \mathrm{~h} \mathrm{EE}$ and body temperature cannot be deduced. Nevertheless, it can be concluded that similar to the interindividual variability of the human metabolic rate (in this study about 5-19\%), there was significant interindividual variability in body temperature, and that persons with higher metabolic rates also had higher core (tympanic) temperature at an ambient temperature of $27^{\circ} \mathrm{C}$.

Why there was a significant relationship between adjusted $24 \mathrm{~h} \mathrm{EE}$ or $16 \mathrm{~h} \mathrm{EE}$ and core temperature at $27^{\circ} \mathrm{C}$ and not at $22^{\circ} \mathrm{C}$ cannot be deduced from this study. One explanation can be that the lower the $\mathrm{EE}$, the larger the (relative) effect is of the contribution of NEAT and thus of the individual differences in NEAT. The effect of the activity component can be larger at relatively high temperatures. On the other hand, part of the variation in $24 \mathrm{~h}$ EE can be due to variation in RMR. The reduction in RMR (ns) at $27^{\circ} \mathrm{C}$ may have resulted in larger individual variation in RMR. Finally, acclimatization may be involved. 
Although we did not find differences between Day 1 and Day 2 at $27^{\circ} \mathrm{C}$, it may well be possible that acclimatization (long-term adaptation) may show different results, and part of the individual differences may be caused by the individual differences in rapidity of acclimatization. Likewise, following acclimatization thermoregulatory function in dry heat did not differ between males and females, which existed before acclimatization [34].

The individual-specific response to a change in ambient temperature from $27^{\circ} \mathrm{C}$ to $22^{\circ} \mathrm{C}$ in $24 \mathrm{~h}$ $\mathrm{EE}$ or $16 \mathrm{~h}$ EE were negatively related to changes in tympanic temperatures between $27^{\circ} \mathrm{C}$ and $22^{\circ} \mathrm{C}$. The change in $24 \mathrm{~h}$ EE (or $16 \mathrm{~h} \mathrm{EE}$ ) from $22^{\circ} \mathrm{C}$ to $27^{\circ} \mathrm{C}$ was significantly related to $T_{\text {tym }}$ at $22^{\circ} \mathrm{C}$ on Day 1 (energy balance). The change in $T_{\mathrm{tym}}$ on Day 1 was also inversely related to $T_{\mathrm{tym}}$. During Day 2 (ad libitum), energy intake was reduced [27], possibly reducing the increase in body temperature at $27^{\circ} \mathrm{C}$, which may have affected the EE. The study thus shows that, when in energy balance, a relatively low body temperature at $22^{\circ} \mathrm{C}$ was associated with a relatively large increase in body temperature at rising ambient temperature. In order to find out what the contribution of $\triangle \mathrm{AEE}$ (or NEAT) was, partial correlation was performed with tympanic temperature and the changes in AEE or $16 \mathrm{~h}$ EE-AEE (i.e., EE minus the activity component). With both $T_{\text {tym }}$ at $22^{\circ} \mathrm{C}$ and with the change in $T_{\text {tym }}$, partial correlation revealed a significant contribution of AEE $(P<.05)$, but not for $16 \mathrm{~h} \mathrm{EE}-\operatorname{AEE}(P>.05)$. This emphasizes the dominant role of NEAT in the decrease in EE at elevated temperatures.

The fact that changing the environmental temperature from $22^{\circ} \mathrm{C}$ to $27^{\circ} \mathrm{C}$, the body temperature gradient decrease was negatively related to the $\mathrm{EE}$ decrease indicates individual differences in response to changing environments. This means that those subjects with hardly any decrease in EE showed a relatively large change in body temperature gradient, while those with a large decrease in EE showed less change in temperature gradients. Responses or adaptations can be metabolic (by changing EE), insulative (by changing vasoconstriction/vasodilation), or by changing the body core temperature [35]. In this study all three adjustments occurred. The relation between changes in gradients and changes in EE (Fig. 4) indicates that individuals confronted with a relatively warm environment differ in the relative contribution of the metabolic response or an insulative response (no change in metabolic rate, change in gradient).

Our data provide strong evidence that individuals regulate body temperatures at different set points, and that the rate of heat production is positively related to the temperature of the body. This has health implications as several studies have shown that a low metabolic rate for a given body composition is a predisposing factor for weight gain [36-38]. It has also been suggested that skin temperature may play a role in the pathogenesis of obesity $[39,40]$. Twin studies indicate that the individual differences in $\mathrm{EE}$ are genetically determined [36,41,42].

Secondly, the data show that individuals differ in their response to a change in ambient temperature. The effect of ambient temperature on individual differences in metabolism and/or thermal adjustments is described in several studies (e.g., Refs. [43-46]). This kind of studies focuses on strong environmental changes, like heat (or cold) stress. However, to our knowledge, the aspect of individual response variability in body temperature and metabolism to mild changes in environmental temperatures, has not been described before. This aspect may have important health implications as individuals may differ in their response to seasonal variations in environmental temperature, but also to short-term changes as ambient temperatures in our society are highly variable (e.g., being inside or outside). A temporal relatively low core temperature, for instance, might have been an energy-conserving mechanism that had survival advantages in the past (see, e.g., relatively low body temperatures in Australian aboriginals during cold nights [47]), but in modern society this may make some individual more prone to obesity than others. The same accounts for the contribution of insulative adjustments or metabolic adjustments. For instance, those subjects with mainly insulative adjustments may be more energy-efficient than those with mainly metabolic adjustments.

Finally, our data indicate that the body temperature at the ambient temperature at which one is acclimatized may have predictive value for the individual response to a change in that ambient temperature: a relatively low $T_{\text {tym }}$ at $22^{\circ} \mathrm{C}$ resulted in a larger increase in $T_{\text {tym }}$ and decrease in $\mathrm{AEE}$ at $27^{\circ} \mathrm{C}$.

In conclusion, our data provide strong evidence that individuals regulate body temperatures at different set points, and that the rate of heat production is positively related to the temperature of the body. Our data also show that individuals differ in their temperature and EE response to a change in ambient temperature, and that these responses were related. The study indicates that the core temperature at baseline may be predictive for the temperature response.

\section{Acknowledgments}

We thank Paul Schoffelen for his assistance with the respiration chamber measurements and Loek Wouters for helping with the body temperature registrations. The enthusiastic support of Caroline Cilissen and Sigrid Top is highly appreciated. 


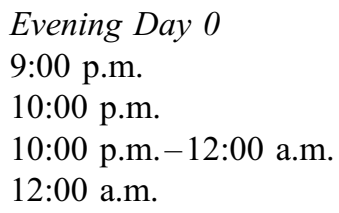

Day 1

8:30-9:30 p.m.

9:30 p.m. $-12: 00$ a.m.

12:00 a.m.
Arrival in respiration chamber. Body weight measurement. Explanations Coffee or tea is served

Unpacking; reading and watching TV, while sitting

Time to go to bed

Wake up. Body weight measurement

Washing and getting dressed

Breakfast

Lying down, reading; not allowed to fall asleep

Dishwashing

Making up the bed

Stepping in standardized rhythm, while music is playing

Refreshing; eating a snack

Calm activity: reading or TV watching while sitting

Playing with a ball

Calm activity: reading or TV watching while sitting

Lunch while sitting

Dishwashing

Calm activity: reading or TV watching while sitting

Stepping in standardized rhythm, while music is playing

Refreshing; preparing and eating a snack

Playing a board game with the neighbour

Lying down, reading or watching TV

Dinner, while sitting. Last $10 \mathrm{~min}$ are spent on dishwashing.

Playing domino with the neighbour

Lying down, reading or watching TV

Eating a snack; calm activity: reading or TV watching while sitting

Time to go to bed

Day 2

8:30-9:00 p.m.

Lying down, reading or watching TV

Leaving the room; body weight measurement

\section{References}

[1] Dauncey MJ. Influence of mild cold on $24 \mathrm{~h}$ energy expenditure, resting metabolism and diet-induced thermogenesis. $\mathrm{Br} \mathrm{J}$ Nutr 1981;45:257-67.

[2] Conzolazio CF, Matoush L-RO, Nelson RA, Torres JB, Isaac GJ. Environmental temperature and energy expenditures. J Appl Physiol 1963;18:65-8.

[3] Valencia ME, McNeill G, Brockway JM, Smith JS. The effect of environmental temperature and humidity on $24 \mathrm{~h}$ energy expenditure in men. Br J Nutr 1992;68:319-27.

[4] Montgomery LD, Williams BA. Effect of ambient temperature on the thermal profile of the human forearm, hand, and fingers. Ann Biomed Eng 1976;4:209-19.

[5] Savage MV, Brengelmann GL. Control of skin blood flow in the neutral zone of human body temperature regulation. J Appl Physiol 1996;80:1249-57.

[6] Brengelmann GL, Savage MV, Avery DH. Reproducibility of core temperature threshold for sweating onset in humans. J Appl Physiol 1994;77:1671-7.
[7] Rising R, Keys A, Ravussin E, Bogardus C. Concomittant interindividual variation in body temperature and metabolic rate. Am J Physiol 1992;263:E730-4.

[8] Rising R, Fontvieille AM, Larson DE, Spraul M, Bogardus C, Ravussin E. Racial difference in body core temperature between Pima Indian and Caucasian men. Int J Obes 1995;19:1-5.

[9] Ravussin E, Swinburn BA. Metabolic predictors of obesity: crosssectional versus longitudinal data. Int J Obes Relat Metab Disord 1993; 17:S28-31.

[10] Blatteis CM. Body temperature. In: Blatteis CM, editor. Physiology and pathophysiology of temperature regulation. London: World Scientific, 1998. p. 394.

[11] Aschoff J, Wever R. Kern und Schale im Wärmehaushalt des Menschen. Naturwiss 1958;45:477-85.

[12] Benzinger TH. Heat regulation: homeostasis of central temperature in man. Physiol Rev 1969;49:671.

[13] Krauchi K, Wirzjustice A. Circadian rhythm of heat production, heart rate, and skin and core temperature under unmasking conditions in men. Am J Physiol 1994;267:R819-29.

[14] Johnson JM, Park MK. Reflex control of skin blood flow by skin 
temperature: role of core temperature. J Appl Physiol 1979;47: $1188-93$.

[15] Webb P. Temperatures of skin, subcutaneous tissue, muscle and core in resting men in cold, comfortable and hot conditions. Eur J Appl Physiol 1992;64:471-6.

[16] Hardy JD, Du Bois EF. Basal metabolism, radiation, convection and vaporization at temperatures of 22 to $35^{\circ} \mathrm{C}$. J Nutr $1938 ; 15$ : 477-97.

[17] Werner J. Control aspects of human temperature regulation. Automatica $1981 ; 17: 351-62$.

[18] Blaza S, Garrow JS. Thermogenic response to temperature, exercise and food stimuli in lean and obese women, studied by $24 \mathrm{~h}$ direct calorimetry. Br J Nutr 1983;49:171-80.

[19] Keys A, Brozek J, Henschel A. The biology of starvation. Minneapolis: University of Minnesota Press, 1950.

[20] Siri WE. Body composition from fluid spaces and density: analysis of methods. In: Bozek J, Henschel A, editors. Techniques for measuring body composition. Washington (DC): National Academy of Sciences, 1961. pp. $223-4$

[21] Schoffelen PFM, Westerterp KR, Saris WHM, Hoor FT. A dual-respiration chamber system with automated calibration. J Appl Physiol 1997;83:2064-72.

[22] Bouten CVC, Pannemans DLE, Westerterp KR, Verduin M. Physical activity assessment during standardized activity in a respiration chamber: movement registration versus energy expenditure. Int $\mathrm{J}$ Obes Relat Metab Disord 1995;19:29.

[23] Weir JB. New methods for calculating metabolic rate with special reference to protein metabolism. J Physiol 1949;109:1-9.

[24] Bouten CV, Marken Lichtenbelt WDv, Westerterp KR. Body mass index and daily physical activity in anorexia nervosa. Med Sci Sports Exercise 1996;28:967-73.

[25] Randall D, Burggren W, French K. Eckert animal physiology: mechanisms and adaptations. New York: Freeman, 1997.

[26] Westerterp KR, Wilson SAJ, Rollnd V. Diet induced thermogenesis measured over $24 \mathrm{~h}$ in a respiration chamber: effect of diet composition. Int J Obes Relat Metab Disord 1998;22.

[27] Westerterp-Plantenga MS, Marken Lichtenbelt WDv, Cilissen C. Energy expenditure and substrate oxidation in humans at an elevated ambient temperature. J Appl Physiol, submitted for publication.

[28] Ravussin E, Bogardus C. Relationship of genetics, age, and physical fitness to daily energy expenditure and fuel utilization. Am J Clin Nutr 1989;49:968-75.

[29] Edge G, Morgan M. The genius infrared tympanic thermmeter. Anaesthesia 1993;48:604-7.

[30] Bricknell MMCM, et al. An evaluation of infra-red tympanic ther- mometry for thermal physiology research. J R Army Med Corps 1997; 143:149-52.

[31] Ducharme MB, Frim J, Bourdon L, Giesbrecht GG. Evaluation of infrared tympanic thermometers during normothermia and hypothermia in humans. Ann NY Acad Sci 1997;813:225-9.

[32] Yeo S, Hayashi RH, Wan JY, Dubler B. Tympanic versus rectal thermometry in pregnant women. JOGNN 1995;24:719-24.

[33] Levine JA, Eberhardt NL, Jensen MD. Role of nonexercise activity thermogenesis in resistance to fat gain in humans (see comments). Science 1999;283:212-4.

[34] Frye AJ, Kamon E, Webb M. Responses of menstrual women, amenorrheal women, and men to exercise in a hot, dry environment. Eur J Appl Physiol 1982;48:279-88.

[35] Jansky L. Human adaptability to cold. Problems with cold work. Stockholm: Arbetslivsinstitutet, 1998.

[36] Ravussin E, Lillioja S, Knowler WC, Christin L, Freymond D, Abbott WGH, Boyce V, Howard BV, Bogardus C. Reduced rate of energy expenditure as a risk factor of body weight gain. $\mathrm{N}$ Engl J Med 1988;318:467-72.

[37] Roberts SB. Energy expenditure and the development of early obesity. Ann NY Acad Sci 1993;699:18-25.

[38] Griffiths M, Payne PR, Stunkard AJ, Rivers JPW, Cox M. Metabolic rate and physical development in children at risk of obesity. Lancet 1990;336:76-8.

[39] Lanzola E, Tagliabue A, Cena H. Skin temperature and energy expenditure. Ann Nutr Metab 1990;34:311-6.

[40] Lanzola E, Tagliabue A, Bozzi G, Meroni G. Obesity, diet and body temperature. Ann Nutr Metab 1991;35:274-83.

[41] Bogardus C, Lilioja S, Ravussin E, Abbott W, Zawadzki JK, Young A, Knowler WC, Jacobowitz R, Moll PP. Familial dependence of the resting metabolic rate. N Engl J Med 1986;315:96-100.

[42] Bouchard C, Tremblay A, Nadeau A, Desprès JP, Thériault G, Boulay MR, Lortie G, Leblanc C, Fournier G. Genetic effect in resting and exercise metabolic rates. Metab Clin Exp 1989;38:364-70.

[43] McArdle WD, Magel JR, Spina RJ, Gergley TJ, Toner MM. Thermal adjustment to cold water exposure in exercising men and women. J Appl Physiol 1984;56:1572-7.

[44] Kenney WL. A review of comparative responses of men and women to heat stress. Environ Res 1985;37:1-11.

[45] Davies CTM. Thermoregulation during exercise in relation to sex and age. Eur J Appl Physiol 1979;42:71-9.

[46] Bar-or O, Lundegren HM, Buskirk ER. Heat tolerance of exercising obese and lean women. J Appl Physiol 1969;26:403-9.

[47] Scholander PF, Hammel HT, Hart JS, LeMessurier DH, Steen J. Cold adaptation in Australian aborigines. J Appl Physiol 1958;13:211-8. 